\title{
Cytotoxic effect of lapatinib is restricted to human papillomavirus-positive head and neck squamous cell carcinoma cell lines
}

This article was published in the following Dove Press journal:

OncoTargets and Therapy

2 February 2014

Number of times this article has been viewed

\author{
Ingrid Fumagalli, ${ }^{1,2}$ \\ Delphine Dugue' \\ Jean Emmanuel Bibault ${ }^{1,2}$ \\ Céline Clémenson' \\ Marie Catherine Vozenin' \\ Michele Mondini ${ }^{1}$ ** \\ Eric Deutsch ${ }^{1,3, *}$ \\ 'Inserm UI030, Molecular \\ Radiotherapy, LABEX LERMIT, \\ Gustave Roussy, University Paris \\ $\mathrm{XI}$, Villejuif, France; ${ }^{2}$ Radiation \\ Therapy Department, Oscar Lambret \\ Comprehensive Cancer Center, Lille, \\ France; ${ }^{3}$ Department of Radiation \\ Oncology, Gustave Roussy, University \\ Paris XI,Villejuif, France \\ *These authors share senior \\ authorship
}

Background: Lapatinib is a dual epidermal growth factor receptor (EGFR) and HER2 inhibitor. Overexpression of these receptors is frequently observed in head and neck squamous cell carcinoma (HNSCC). As growing proportion of HNSCC is characterized by human papillomavirus (HPV) infection, we aimed at evaluating the efficacy of lapatinib as function of HPV status in HNSCC cell lines.

Methods: Two HPV-positive and two HPV-negative HNSCC cell lines were used. Proliferation, cell cycle, and Annexin V assays were performed to test their sensitivity to lapatinib. Combination of lapatinib and ionizing radiation was evaluated with clonogenic survival assays. Akt, EGFR and HER2, and E6/E7 expression and activation were analyzed by immunoblotting and quantitative reverse transcription polymerase chain reaction.

Results: Lapatinib reduced E6 and E7 expression and Akt phosphorylation, inhibited cell proliferation and induced cell death in HPV-positive cell lines. An additive effect of lapatinib with radiation was observed in these cells. Lapatinib had no effect on HPV-negative cells.

Conclusion: Lapatinib efficacy restricted to the HPV-positive cells suggests that HPV status could be a potential marker for enhanced response to lapatinib in HNSCC.

Keywords: HPV, lapatinib, ionizing radiation, EGFR, HER2, tyrosine kinase inhibitor

\section{Introduction}

Head and neck squamous cell carcinoma (HNSCC) is a challenge in oncology. Despite the improvement of therapies, $40 \%-50 \%$ of patients treated for HNSCC experience recurrence. ${ }^{1}$ Treatment is generally limited to surgery, platinum-based chemotherapy, and radiotherapy (RT). However, since toxicity and insufficient efficacy are frequent and limiting, targeted molecular therapy has been investigated in the last 20 years. ${ }^{2}$ The spectrum of known risk factors is growing. The human papillomavirus (HPV) infection has emerged as an important one, accounting for an increasing proportion of HNSCC. ${ }^{3}$ HPV-positive tumors differ from HPV-negative tumors in many aspects, including histological appearance and differentiation. ${ }^{4} \mathrm{HPV}$-positive tumors are associated with better prognosis, but the reasons for this remain unclear. Some studies suggested that increased sensitivity to radiation in HPV-positive tumors could account for improved prognosis in these patients. .,6 $^{5}$ The identification of new, more effective treatments for such cancers, specifically administered depending on the HPV status, could be very useful in the clinical therapy.

The epidermal growth factor receptor (EGFR) family contains four tyrosine kinase transmembrane receptors: EGFR (ErbB1), HER2 (ErbB2), HER3 (ErbB3), and HER4 (ErbB4). These receptors transmit signals through intracellular pathways that regulate
Correspondence: Eric Deutsch Gustave Roussy Cancer Campus, II 4 rue Edouard Vaillant, 94805 Villejuif Cedex, France $\mathrm{Tel}+33$ I $44 \mid$ I 5296

Fax +33 | 44|| 5296

Email eric.deutsch@gustaveroussy.fr 
proliferation, survival, cell cycle progression, and angiogenesis. $^{7}$ In HNSCC, EGFR and HER2 are frequently overexpressed, ${ }^{8,9}$ and these alterations correlate with the worse overall survival. ${ }^{10-12}$ EGFR family members thus represent prominent and attractive molecular targets for therapeutic intervention in HNSCC. The relationship between EGFR expression and HPV status is also important. HPV-positive tumors with low EGFR expression are associated with positive response, whereas HPV-positive tumors with high EGFR expression are associated with poor outcome. ${ }^{13}$ These results further support the interest in blocking the EGFR pathway.

Cetuximab, a monoclonal antibody EGFR inhibitor, has shown promising therapeutic effects in HNSCC. ${ }^{14}$ Other tyrosine kinase inhibitors (TKIs), used in monotherapy, such as gefitinib or erlotinib, have been developed and tested. ${ }^{15,16}$ More recently, strategies targeting both EGFR and HER 2 have been proposed; these combination strategies are expected to be more effective than mono-inhibitors. ${ }^{17,18}$ Nevertheless, published studies with anti-EGFR family members, such as cetuximab, gefitinib, erlotinib, lapatinib, and panitumumab, in cervical carcinoma and HNSCC (summarized in Table 1) show discordant results, suggesting that further studies are required to optimize the efficacy of these molecules.

Lapatinib is a reversible dual EGFR and HER2 inhibitor. Lapatinib binds to the ATP-binding pocket of the EGFR and

Table I EGFR family inhibitors in cervical carcinoma and HNSCC

\begin{tabular}{|c|c|c|c|c|c|c|}
\hline Drug & Organ & Authors & Phase & Treatment & Stage of disease & Results \\
\hline \multirow[t]{9}{*}{ Cetuximab } & Cervix & Santin et $\mathrm{al}^{38}$ & II & Drug alone & Persistent or recurrent & $\begin{array}{l}\text { Well tolerated, limited to patients } \\
\text { with squamous cell histology }\end{array}$ \\
\hline & & Farley et $\mathrm{al}^{39}$ & II & Cisplatin & $\begin{array}{l}\text { Advanced, persistent, } \\
\text { recurrent }\end{array}$ & $\begin{array}{l}\text { No indication of additional benefit } \\
\text { beyond cisplatin therapy }\end{array}$ \\
\hline & & Kurtz et $\mathrm{al}^{40}$ & II & Cisplatin + topotecan & Advanced & $\begin{array}{l}\text { High rate of serious adverse fatal } \\
\text { events }\end{array}$ \\
\hline & HNSCC & Bourhis et $\mathrm{al}^{41}$ & $\mathrm{I} / \mathrm{II}$ & $\begin{array}{l}\text { Cisplatin/ } \\
\text { carboplatin }+5 \mathrm{FU}\end{array}$ & Recurrent or metastatic & $\begin{array}{l}\text { Well tolerated, active in } \\
\text { recurrent/metastatic HNSCC }\end{array}$ \\
\hline & & Merlano et $\mathrm{al}^{42}$ & II & Cisplatin + 5FU + RT & Stage III-IV MO & Very high proportion of CR feasible \\
\hline & & Baselga et $\mathrm{al}^{43}$ & II & Platin & Recurrent or metastatic & Active and well tolerated \\
\hline & & Bonner et $\mathrm{al}^{14}$ & III & Cisplatin + RT & $\begin{array}{l}\text { Locoregionally } \\
\text { advanced }\end{array}$ & $\begin{array}{l}\text { Improves locoregional control and } \\
\text { reduces mortality }\end{array}$ \\
\hline & & Burtness et $\mathrm{al}^{44}$ & III & Cisplatin & Recurrent, metastatic & $\begin{array}{l}\text { Improves response rate, } \\
\text { progression-free and overall } \\
\text { survival not significantly improved }\end{array}$ \\
\hline & & Vermorken et $\mathrm{al}^{45}$ & III & Platin $+5 \mathrm{FU}$ & Recurrent, metastatic & Improvement in OS \\
\hline \multirow[t]{2}{*}{ Panitunumab } & HNSCC & Giralt et $\mathrm{al}^{30}$ & II & Cisplatin + RT & Non-treated stage III-IV & No improvement \\
\hline & & Vermorken et $\mathrm{a}^{29}$ & III & Platin & Recurrent or metastatic & $\begin{array}{l}\text { OS and PFS improvement for } \\
\text { HPV negative }\end{array}$ \\
\hline \multirow[t]{5}{*}{ Gefitinib } & Cervix & Goncalves et $\mathrm{al}^{46}$ & II & Drug alone & $\begin{array}{l}\text { Locally advanced } \\
\text { metastatic }\end{array}$ & $20 \%$ of stable disease \\
\hline & HNSCC & Chen et $\mathrm{al}^{47}$ & 1 & $\mathrm{RT} \pm$ cisplatin & Locally advanced & $\begin{array}{l}\text { Well tolerated with concomitant } \\
\text { boost RT or concurrent CRT }\end{array}$ \\
\hline & & Perez et $\mathrm{al}^{48}$ & II & Drug alone & Recurrent, metastatic & Active and feasible \\
\hline & & Gregoire et al $^{49}$ & III & Cisplatin + RT & $\begin{array}{l}\text { Untreated, } \\
\text { unresected, stage III/IV } \\
\text { nonmetastatic }\end{array}$ & $\begin{array}{l}\text { Well tolerated, no improvement } \\
\text { in efficacy }\end{array}$ \\
\hline & & Cohen et $\mathrm{al}^{50}$ & III & Carbo/paclitaxel + RT & Locally advanced & OS and CR improvement \\
\hline \multirow[t]{6}{*}{ Erlotinib } & Cervix & Nogueira-Rodrigues et $\mathrm{al}^{51}$ & $\mathrm{I}$ & Cisplatin + RT & IIB and IIIB stages & Feasible \\
\hline & & Schilder et $\mathrm{al}^{52}$ & II & Drug alone & Recurrent & Inactive \\
\hline & HNSCC & Rusthoven et $\mathrm{al}^{53}$ & $\mathrm{I}$ & RT (3 regimens) & All stages & Feasible \\
\hline & & Arias de la Vega et al ${ }^{54}$ & 1 & Cisplatin + RT & Locally advanced & Safe combination \\
\hline & & Soulieres et $\mathrm{al}^{55}$ & II & Drug alone & Recurrent or metastatic & Stabilized diseases \\
\hline & & Herchenhorn et $\mathrm{al}^{56}$ & $\mathrm{I} / \mathrm{II}$ & Cisplatin/RT & Locally advanced & Feasible and well tolerated \\
\hline \multirow[t]{2}{*}{ Lapatinib } & HNSCC & Harrington et $\mathrm{al}^{23}$ & II & Cisplatin/RT & Locally advanced & $\begin{array}{l}\text { Well tolerated, positive clinical } \\
\text { activity }\end{array}$ \\
\hline & & Del Campo et $\mathrm{al}^{57}$ & II & Drug alone & Before CRT & $\begin{array}{l}\text { Positive clinical activity, reduction } \\
\text { of cell proliferation index }\end{array}$ \\
\hline
\end{tabular}

Abbreviations: HNSCC, head and neck squamous cell carcinoma; RT, radiotherapy; OS, overall survival; PFS, progression-free survival; HPV, human papillomavirus; CRT, chemoradiotherapy; 5FU, 5-fluorouracil; CR, complete response. 
HER2 protein kinase domain, preventing self-phosphorylation of the receptors and signaling activation. ${ }^{19}$ The drug is administered orally and has already been used with success in some pathologies, such as locally advanced or metastatic breast cancer. ${ }^{20}$ Several trials have shown that lapatinib can be combined with RT both safely ${ }^{21,22}$ and effectively. ${ }^{23}$ Phase III clinical studies assessing the relationship between HPV status, treatment with TKIs, and ionizing radiation have not yet been completed in HNSCC, but the results obtained in cervical cancers (about $90 \%$ are HPV positive) ${ }^{24}$ are controversial, demonstrating only little benefits of using TKIs or an antibody combined with radiation (Table 1). In vitro, other TKIs (erlotinib) have shown growth inhibition and prevented immortalization of HPV-transfected cell lines. ${ }^{25}$ An HNSCC tumor xenograft showed that erlotinib combined with RT dramatically inhibited tumor growth. ${ }^{26}$ These data may suggest a benefit of using the combination of ionizing radiation and lapatinib in HNSCC cell lines. The purpose of this study was to evaluate the efficacy of lapatinib alone or in combination with ionizing radiation as function of HPV status in four HNSCC cell lines.

\section{Materials and methods Drug}

Lapatinib was provided as powder by GlaxoSmithKline (GSK; London, UK). A $10^{-2} \mathrm{M}$ concentrated stock solution was obtained after solubilization in dimethylsulfoxide (DMSO).

\section{Cell culture}

Four cell lines were used, including two HPV-positive and two HPV-negative cell lines. Cell lines were maintained at $37^{\circ} \mathrm{C}$ with $5 \%$ carbon dioxide. SCC-9, derived from a tongue epidermal carcinoma, was obtained from American Type Culture Collection (ATCC; ATCC Number: CRL-1629) and certified as negative for HPV. SCC-15 is also derived from a tongue HNSCC and was obtained from the ATCC (ATCC Number: CRL-1629) and certified as negative for HPV. These two cell lines were maintained in Dulbecco's Modified Eagle Medium/F-12 (Gibco Invitrogen) with 10\% fetal bovine serum (FBS), $1 \%$ penicillin/streptomycin $(\mathrm{P} / \mathrm{S}$; 10,000 units/mL penicillin and $10,000 \mathrm{~g} / \mathrm{mL}$ streptomycin), and $400 \mathrm{ng} / \mathrm{mL}$ hydrocortisone. The HPV16-positive UMSCC-47 cell line was derived from an oropharynx HNSCC and obtained from T Carey, University of Michigan, Ann Arbor, MI. The cells were maintained in Dulbecco's Modified Eagle Medium with 10\% FBS, $1 \% \mathrm{P} / \mathrm{S}$, and $1 \%$ nonessential amino acids. SCC-154 cells, derived from a tongue epidermoid carcinoma, were obtained from Deutsche Sammlung von Mikroorganismen und Zellkulturen (DSMZ Number: ACC 669; Heidelberg, Germany) and are HPV16 positive. SCC-154 cells were maintained in Minimal Essential Medium supplemented with 10\% FBS, $1 \% \mathrm{P} / \mathrm{S}$, and $1 \%$ nonessential amino acids.

\section{Reverse transcription PCR}

Quantitative polymerase chain reaction (PCR) analysis was performed to compare the expression of the E6 and E7 oncoproteins between each cell line. RNA extraction was performed using Qiagen RNeasy kit, and the samples were treated with DNAse-I (Qiagen). One microgram of total RNA was retrotranscribed using the Bio-Rad ${ }^{\circledR}$ I-Script kit. Quantitative PCR was performed using the primers listed in Table S1, used at $400 \mathrm{nM}$ concentration. The transcript levels of E6 and E7 were normalized to those of $\beta-2$ microglobulin to account for variability in the amount of cDNA in each sample. SYBR Green Mix (Applied Biosystems) was used with the GeneAmp 7900HT Sequence Detection System (Applied Biosystems, Foster City, CA, USA) using a twostep amplification protocol (Table S1). The relative transcript expression levels were calculated using the $\Delta \Delta \mathrm{CT}$ method, using vehicle-treated cells as calibrator.

\section{Proliferation assays}

Cells (2,000 cells/well for SCC-9 and SCC-47 and 4,000 cells/ well for SCC-15 and SCC-154) were seeded in 96-well plates in a final culture volume of $100 \mu \mathrm{L}$ for 16 hours before the addition of $100 \mu \mathrm{L}$ of increasing concentrations of lapatinib (from $1.5 \mathrm{nM}$ to $10 \mu \mathrm{M}$ ). The plates were incubated for 48 hours after the drug was added. The viable cell number was determined using a $10 \%$ concentration of UptiBlue reagent (Interchim, France). The analyses were performed by fluorimetry and normalized to a non-treated control. IC50 values represent the concentration which reduces by $50 \%$ the number of viable cells.

\section{Cell cycle analysis and Annexin $\vee$ staining}

Cells were treated with vehicle, lapatinib, or staurosporine for 24 hours after plating. One day later, cells were harvested, washed with ice-cold phosphate-buffered saline, and fixed with $70 \%$ ethanol. DNA content was labeled with propidium iodide (PI) in the presence of RNase (phosphate-buffered saline buffer supplemented with PI $20 \mu \mathrm{g} / \mathrm{mL}$, RNase $100 \mu \mathrm{g} /$ $\mathrm{mL}$, and ethylenediaminetetraacetic acid $20 \mathrm{mM}, \mathrm{pH}$ 8). Cells were then incubated for 1 hour at $37^{\circ} \mathrm{C}$. FACSCalibur (Becton Dickinson) was used to perform the flow cytometry assay. 
At the same time point, dead and apoptotic cells were detected using a fluorescein isothiocyanate-labeled Annexin V kit (Myltenyi Biotec) following manufacturer's instructions.

\section{Clonogenic survival assays}

To determine the sensitivity of the HNSCC cell lines to radiation, we performed clonogenic survival assays. Cells were plated at several low densities depending on the dose rate and incubated for 16 hours at $37^{\circ} \mathrm{C}$ in $5 \%$ carbon dioxide (Table S2). The cells were then treated with $1 \mu \mathrm{M}$ lapatinib or DMSO (vehicle) in duplicate. The cells were incubated for 4 hours, and then irradiated (IBL-637, cesium 137, dose rate of $1 \mathrm{~Gy} / \mathrm{min}$ ). The culture medium was changed 24 hours after treatment. After 6-20 days, cells were fixed and stained with crystal violet solution. Colonies containing $>50$ cells were counted. The surviving fraction was determined as the total number of colonies formed divided by the total number of cells plated multiplied by the plating efficiency, as determined in unirradiated cells in the presence of drug exposure.

\section{Immunoblotting analysis}

Western blotting was performed to detect pAKT, AKT, pEGFR, EGFR, pHER2, and HER2. Cells were treated 16 hours after plating in complete medium (containing FBS). Lapatinib ( $1 \mu \mathrm{M})$ or DMSO (vehicle) was added for 24 hours, and then proteins were extracted by sodium dodecyl sulfate lysis buffer (Tris-HCl 125 mM, 20\% glycerol, and 4\% SDS). Protein content was evaluated using a Bio-Rad ${ }^{\circledR}$ kit, and $10 \mu \mathrm{g}$ of protein sample was loaded on a denaturing acrylamide NuPage Bis-Tris gel (Invitrogen). After migration, the proteins were transferrsed to nitrocellulose membrane. Antibodies used are listed in Table S3. Normalization was performed using an anti- $\beta$-actin antibody. Enhanced chemiluminescence (Amersham, Western Blotting Analysis System; GE Healthcare) was used for detection.

\section{Statistical analysis}

Statistical analyses were performed using GraphPad Prism Version 6. Paired $t$-test was used to evaluate differences in gene expression and Akt phosphorylation between lapatiniband vehicle-treated cells. One-way analysis of variance was used to determine differences in Annexin V staining.

\section{Results}

\section{Lapatinib reduces the expression of $\mathrm{E} 6$ and $\mathrm{E7}$ oncogenes}

SCC-47 and SCC-154 cells are depicted as HPV positive. While the effective transcription and levels of the E6 and E7 oncogenes have been reported for SCC-47 cells, ${ }^{5}$ they have not been previously described for SCC- 154 cells. Therefore, we performed quantitative RT-PCR, which showed similar levels of E6 and E7 in the two HPV-positive cell lines (data not shown). We evaluated if lapatinib treatment could affect the expression of the two transcripts. As shown in Figure 1, lapatinib significantly decreased E6 and E7 mRNA levels in both cell lines, with the exception of E6 in SCC-47, which was nevertheless close to statistical significance. As expected, E6 or E7 expression was not detected in SCC-9 and SCC-15, confirming the HPV-negative status of these cells (data not shown).

\section{Lapatinib induces cell death of HPV-positive cells}

We sought to determine whether lapatinib exerted an antiproliferative activity on the four HNSCC cell lines. Lapatinib efficiently reduced cell proliferation of the two HPV positive cell lines tested, with IC50 values of $0.36 \mu \mathrm{M}$ (IC95 = $0.18 \mu \mathrm{M}-0.69 \mu \mathrm{M})$ and $0.02 \mu \mathrm{M}(\mathrm{IC} 95=0.005 \mu \mathrm{M}-0.08 \mu \mathrm{M})$
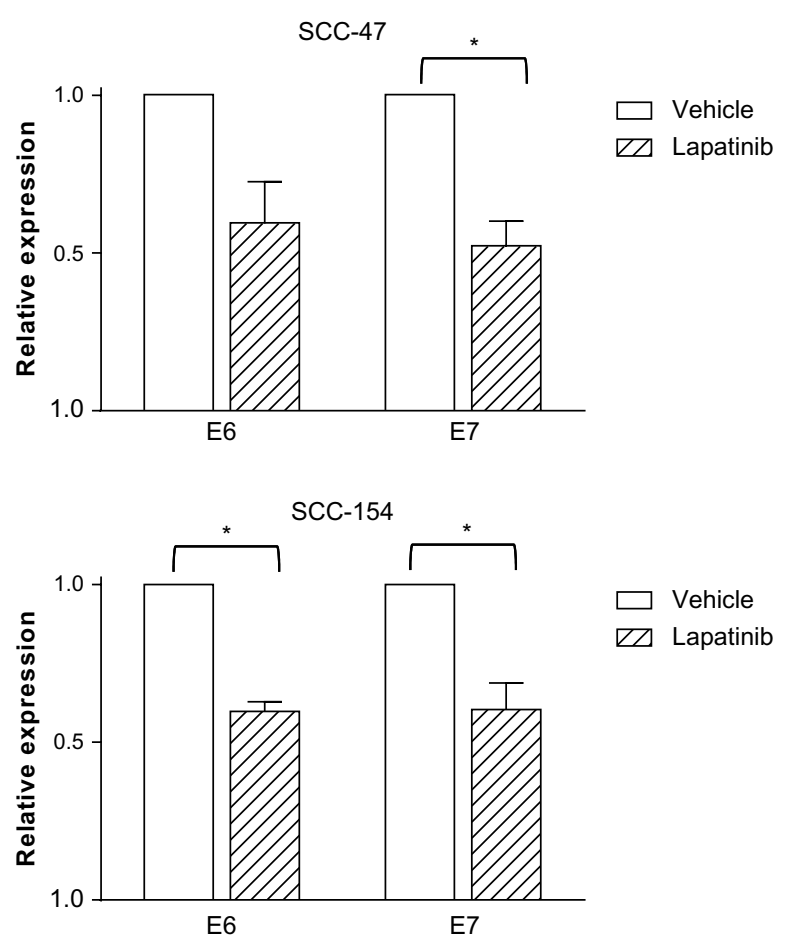

Figure I E6 and E7 transcripts in SCC-47 and SCC-154 cells are decreased by lapatinib.

Notes: RNA was extracted from two HPV-positive (SCC-47 and SCC-154) and two HPV-negative (SCC-9 and SCC-15) cell lines treated with vehicle or I $\mu$ M lapatinib for 24 hours. Transcript levels were evaluated by quantitative RT-PCR and normalized with $\beta$-2 microglobulin. The relative RNA expression levels were calculated using the $\Delta \triangle C T$ method, by normalizing to vehicle-treated cells. No amplification of the two transcripts was observed in the HPV-negative cell lines (SCC-9 and SCC-15). Data are the mean of three experiments. $* P<0.05$, paired $t$-test.

Abbreviations: HPV, human papillomavirus; RT-PCR, reverse transcription polymerase chain reaction. 

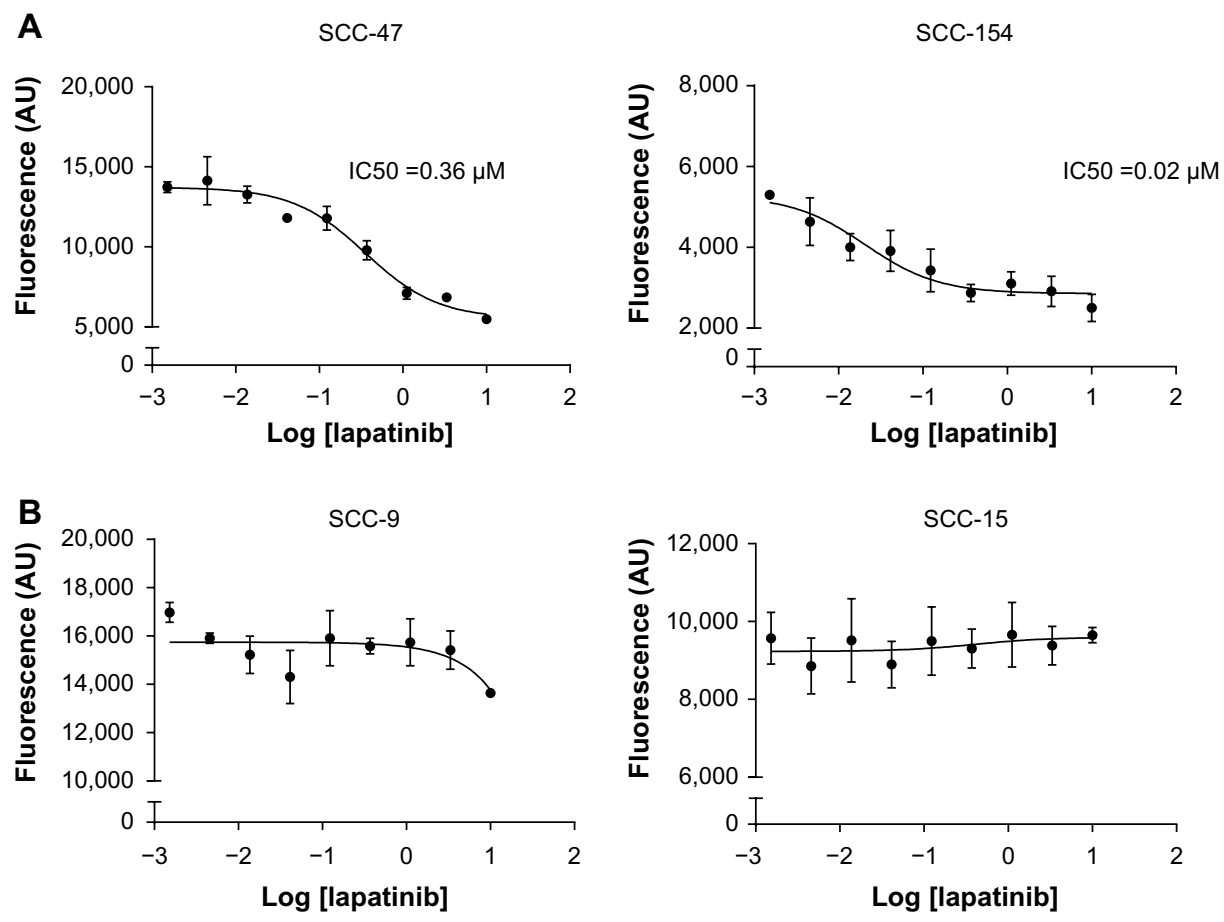

Figure 2 Lapatinib affects proliferation of HPV-positive cells.

Notes: Cells were seeded in 96-well plates for 16 hours before the addition of increasing concentrations of lapatinib (ranging from I.5 $\mathrm{nM}$ to $10 \mu \mathrm{M}$ ). Forty-eight hours later, the viable cell number was determined by fluorimetry using a $10 \%$ concentration of UptiBlue reagent. The dose-response curves are shown on a semi-logarithmic scale for HPV-positive (A) and HPV-negative cell lines (B).

Abbreviation: HPV, human papillomavirus.

(Figure 2A). In contrast, IC50 values could not be determined in the 2 HPV-negative cells lines, SCC-9 or SCC-15, because doses up to $10 \mu \mathrm{M}$ Lapatinib did not result in a significant inhibition of the proliferation on these cells (Figure 2B). Thus, the antiproliferative effect of lapatinib was restricted to the HPV-positive cell lines.

To better characterize the mechanism of action of lapatinib on HPV-positive cells, we performed cell cycle analysis and evaluated the onset of apoptosis after treatment with lapatinib. No significant modulation of the distribution of cells in the different phases of the cell cycle was observed upon lapatinib treatment (Figure 3A). By contrast, in the same conditions, cytofluorimetric analysis showed a significant increase in Annexin V staining (Figure 3B), indicating that lapatinib induces cell death in these cells. A growing trend of the proportion of Annexin V+, PI- cells, corresponding to cells undergoing apoptosis, was observed upon lapatinib treatment. As expected, incubation with staurosporine, used as positive control for apoptosis induction, efficiently induced Annexin V exposure.

\section{Inhibition of EGFR and HER2 signaling by lapatinib is limited to HPV-positive cells}

In an effort to clarify the molecular basis underlying the differential effects of lapatinib according to HPV status, we performed immunoblotting analysis to assess the expression level and the phosphorylation status of EGFR, HER2, and their downstream effector Akt. A 24-hour treatment with lapatinib, performed on cells plated in complete medium, induced a decrease in EGFR phosphorylation in SCC-47 and SCC-154 cells, even if in the latter cell line we could detect only a weak signal corresponding to the phosphorylated receptor (Figure 4A). In contrast, no modulation was observed in the HPV-negative cells (Figure 4B). Inhibition of HER2 phosphorylation was observed in all cell lines (Figure 4). In the HPV-positive cells, a significant decrease in Akt phosphorylation was observed upon lapatinib treatment (Figure 4A), of approximately $85 \%$ in both cell lines (see quantification in Figure 4A, right panels), in accord with the inhibition of receptor signaling. Oppositely, no modulation of Akt activation was observed in HPV-negative cell lines, indicating that Akt activation could be sustained by HER2independent mechanisms in the SCC-9 and SCC-15 cells. Total protein levels were not significantly altered in all conditions tested.

The absence of Akt modulation after lapatinib treatment in HPV-negative cells is consistent with the lack of antiproliferative efficacy of lapatinib in these cells. 


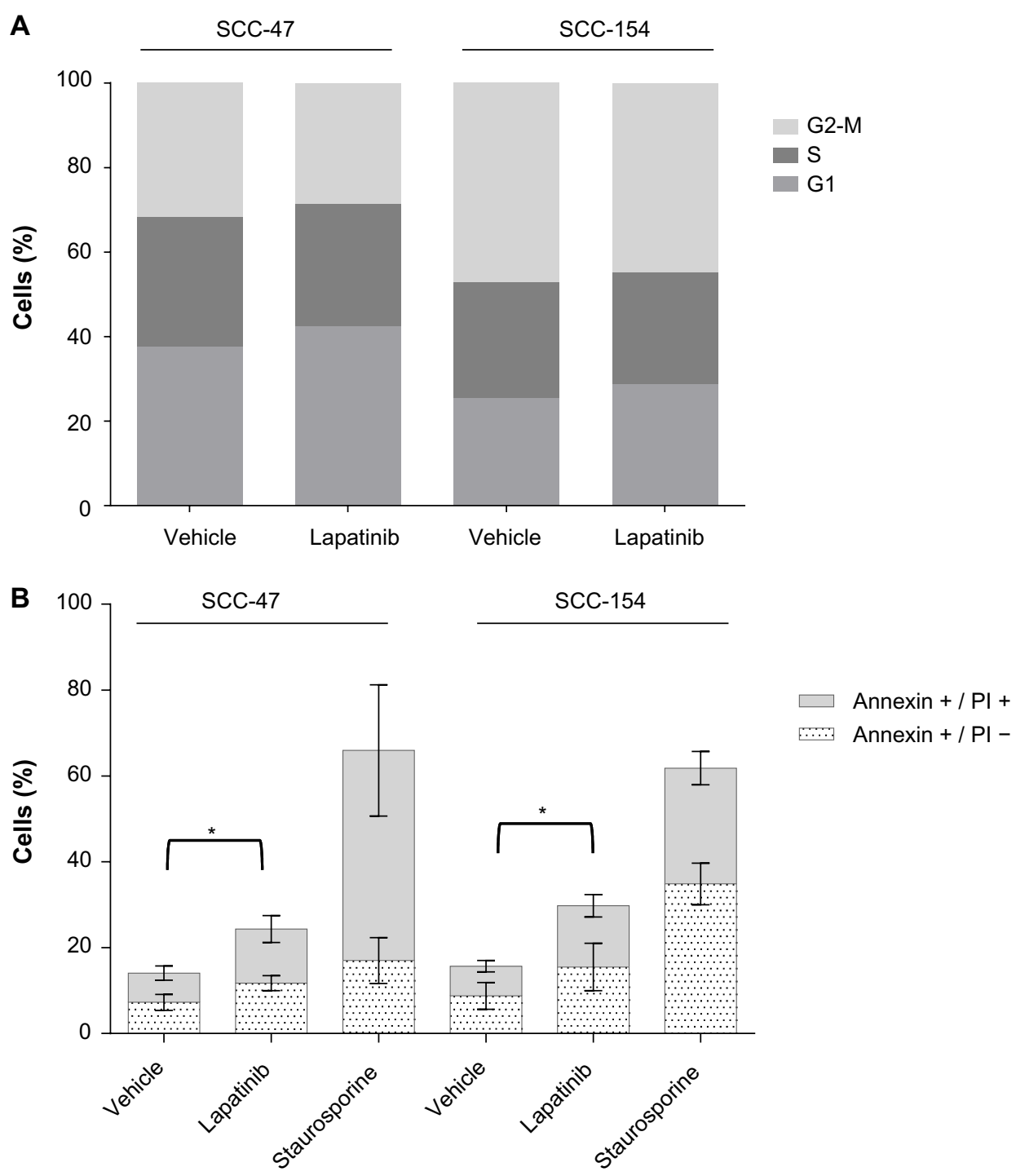

Figure 3 Annexin $V$ exposure is induced by lapatinib treatment of HPV-positive cells.

Notes: Cell cycle analysis was performed by flow cytometry on cells treated for 24 hours with vehicle or I $\mu M$ lapatinib (A). Annexin $V$ detection was performed, in combination with PI staining, to detect dead (Annexin $\mathrm{V}+/ \mathrm{PI}+$ ) and apoptotic (Annexin $\mathrm{V}+/ \mathrm{PI}-$ ) cells (B). Staurosporine I $\mu \mathrm{M}$ was used as a positive control for apoptosis induction. Data are the mean of three independent experiments. ${ }^{*} P<0.05$, one-way analysis of variance for the comparison of total number of Annexin $V+$ cells.

Abbreviations: HPV, human papillomavirus; PI, propidium iodide.

\section{Lapatinib does not exert a}

\section{radiosensitizing effect in HNSCC cells}

We next investigated whether lapatinib could modulate the sensitivity of HNSCC cells to ionizing radiation by performing a clonogenic assay. Four hours before radiation exposure, cells were treated with $1 \mu \mathrm{M}$ lapatinib to ensure sustained receptor inhibition in the lapatinib-sensitive cell lines. In the HPV-positive cell lines, lapatinib reduced the surviving fraction by $35 \%$ and $80 \%$ in SCC- 47 and SCC-154, respectively (data not shown). No significant radiosensitizing effect was shown, although a limited trend toward decreased survival was detected in SCC-154 cells (Figure 5). As expected, we did not observe any significant effect of lapatinib treatment on the HPV-negative cells, consistent with the lack of efficacy of the drug on cell proliferation and on Akt activation.

\section{Discussion}

We tested the effects of lapatinib using multiple cellular models of HNSCC. This dual EGFR and HER2 inhibitor was tested in two HPV-positive and two HPV-negative cell lines, and was found to decrease AKT phosphorylation, a pivotal mediator of receptor tyrosine kinases signaling, in HPV-positive but not in HPV-negative cell lines. Accordingly, the induction of cell death by lapatinib was restricted to the HPV-positive cells. Of great interest, treatment with lapatinib reduced the levels of mRNAs coding for the two major HPV 

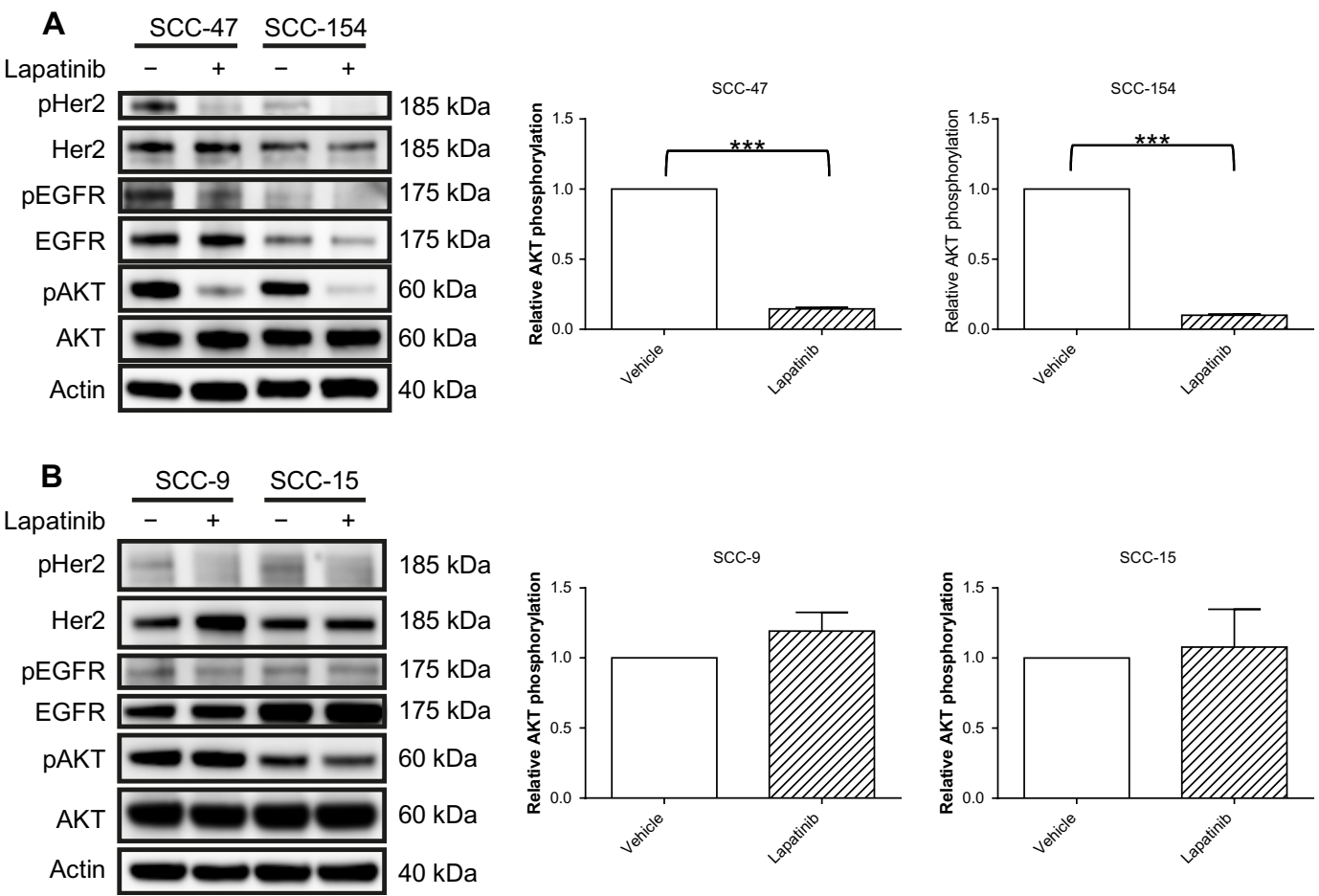

Figure 4 Lapatinib treatment inhibits AKT signaling in HPV-positive cells.

Notes: Cells were treated with lapatinib $(\mathrm{I} \mu \mathrm{M})$ or DMSO (vehicle control) 16 hours after plating. After 24-hour treatment, protein extraction was performed. The phosphorylation and levels of EGFR (Tyr I068), HER2 (Tyr I 22I/I222), and AKT (Ser473) were analyzed by Western blotting of HPV-positive (A) and HPV-negative cell lines (B). Beta-actin immunoblotting was used as a loading control. A representative picture of three independent experiments is shown. Quantification of AKT and pAKT was performed by densitometric analysis, and the mean ratio of PAKT/AKT from three independent experiments is depicted in the right panels. $* * * P<0.00 \mathrm{I}$, paired $t$-test. Abbreviations: HPV, human papillomavirus; DMSO, dimethylsulfoxide.

A

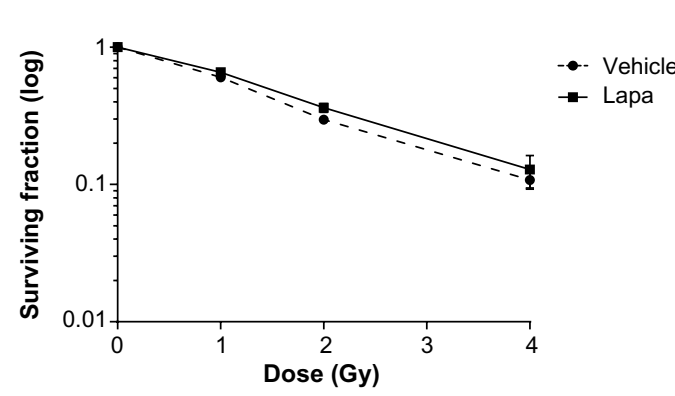

B

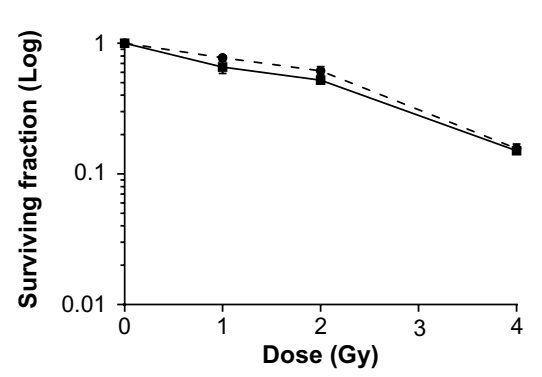

SCC-154
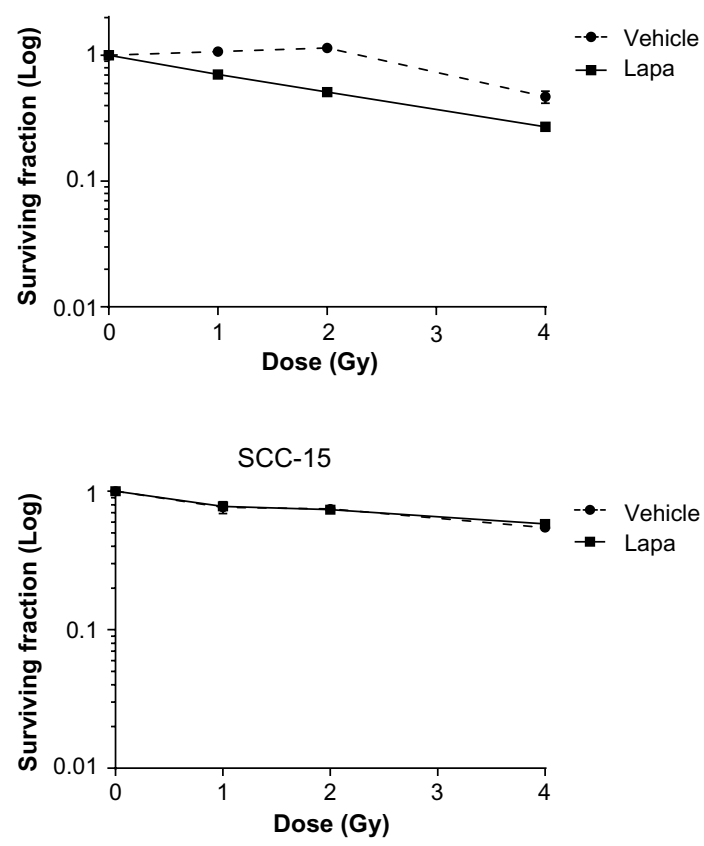

Figure 5 Lapatinib treatment does not affect radiation sensitivity of HNSCC cells.

Notes: HPV-positive cells (A) and HPV-negative cells (B) treated with I $\mu$ M lapatinib or DMSO (vehicle) were irradiated 4 hours later. Lapatinib was eliminated thanks to a medium removal 24 hours later. Colonies were stained with crystal violet solution. The surviving fraction was determined as the total number of colonies formed divided by the total number of cells plated multiplied by the plating efficiency, as determined in unirradiated cells in the presence of drug exposure. Abbreviations: HNSCC, head and neck squamous cell carcinoma; HPV, human papillomavirus; DMSO, dimethylsulfoxide; Lapa, lapatinib. 
oncogenes, E6 and E7. Even if this data needs to be confirmed by further observation (as restoration of p53 expression or $\mathrm{pRb}$ phosphorylation), reduction of papillomavirus oncogenes expression can contribute to the efficacy of lapatinib in HPVpositive cells. Consistent with the antiproliferative effect observed in the proliferation assay, clonogenic assay showed that lapatinib caused a reduction in clone size, which was limited to HPV-positive cells (data not shown). Nevertheless, we did not observe significant radiosensitization of these cell lines in clonogenic assays. This observation suggests that in these cellular models, survival to ionizing radiation could not be primarily due to AKT signaling. The results reported in the literature regarding the radiosensitizing effect of lapatinib are controversial. Zhou et al have reported radiosensitization in some cell lines but radioresistance in others upon treatment with lapatinib and ionizing radiation. ${ }^{27}$ In their work, one of the four cell lines tested was resistant to the antiproliferative and radiosensitizing effects of lapatinib, despite receptor inhibition. The proposed mechanism for resistance was the lack of Akt inhibition. By contrast Sambade et al reported that in breast cancer cells, radiosensitization by lapatinib is mediated primarily through inhibition of MEK/ERK pathway. ${ }^{28}$ Given that in all HNSCC cell lines tested we did not observe any radiosensitizing effect, it will be thus of interest to analyze if MEK/ERK activation is unchanged by lapatinib treatment in these cells and we will explore this possibility in our future works. Recently, similar discordant results have been observed in clinical studies of panitumumab, an anti-EGFR monoclonal antibody. ${ }^{29,30}$ Moreover, our results are in line with the effects of sorafenib, a broad-spectrum TKI. ${ }^{31}$ Pretreatment with sorafenib for $2-3$ hours, at 24 hours and 48 hours, before radiation reduced the plating efficiency of HCT116 and SW480 cells but did not affect the relative surviving fraction.

Interestingly, lapatinib did not significantly affect the proliferation of the two HPV-negative cell lines tested at concentrations of up to $10 \mu \mathrm{M}$. In a previous study, published in 2007 by Rusnak et al, the IC50 values for lapatinib in SCC-9 and SCC-15 were $0.331 \mu \mathrm{M}$ and $0.267 \mu \mathrm{M}$, respectively. ${ }^{32}$ The difference between that study and our results may be a consequence of the different conditions used to perform the proliferation assays and different viability detection methods (methylene blue staining vs fluorescence-based REDOX indicator). Our results demonstrating negligible activity of lapatinib in SCC-9 and SCC-15 are consistent with those of clonogenic assays because no effects were observed, even on clone size (data not shown). Moreover, Western blot analysis demonstrated a decrease in HER2 phosphorylation (as expected, given the direct activity of lapatinib on the receptor), but this inactivation was not sufficient to inhibit activation of the PI3K/AKT pathway. Accordingly, we did not observe a radiosensitization effect of lapatinib.

Our study indicates a potential relation of HPV status and response to lapatinib. Nevertheless, it should be stressed that this observation, although indicative, is restricted to the limited cell lines tested. A generalization of the predictive value of HPV status for lapatinib efficacy will require screening of additional HNSCC cell lines and confirmation using gain-of-function and loss-of-function experiments, such as transfection of HPV oncogenes or RNAi against E6 and E7 transcripts. In preliminary experiments, we treated primary normal human and HPV18-immortalized keratinocytes with lapatinib, but lapatinib treatment was toxic to both cell lines and prevented us from carrying out clonogenic and immunoblotting analysis. Moreover, it should be noted that the effects of lapatinib in vivo may be significantly different as a consequence of influence of the tumor microenvironment and interplay with stromal cells. Further studies using animal models will be required to address this point.

The expression of HPV oncogenes in the HPV-infected cells could potentially affect the signaling pathway of EGFR and HER2, thus accounting for the differing sensitivity to lapatinib. A recent publication showed that E6 from HPV16 enhances the signaling of EGFR by activating mTORC1, and increases the internalization of activated receptors. ${ }^{33}$ Moreover, it has been demonstrated that HPV16 E5 inhibits the degradation of the EGFR in endosomal compartments, inducing prolonged retention of undegraded EGFR in intracellular vesicles. ${ }^{34}$ Finally, since EGFR signaling has been shown to be pivotal for the transforming activity of HPV16 $\mathrm{E} 6 / \mathrm{E} 7,{ }^{25}$ it is conceivable to hypothesize that HPV-positive cells could be particularly responsive to EGFR inhibition.

EGFR family receptors are targets of interest in the clinical setting because they trigger pathways involved in the pathogenesis of human epithelial tumors. Thus, several molecules targeting these receptors have been developed and are currently being tested in squamous cell carcinomas. Heterogeneous results have been observed in cervical cancer and HNSCC (Table 1). Cetuximab, a monoclonal antibody targeting the extracellular binding domain of EGFR, has already demonstrated efficacy, in combination with RT, in an HNSCC phase III randomized study. ${ }^{14}$ However, the results of EGFR inhibitor use as monotherapy are not conclusive. ${ }^{35}$ For example, the first trials of TKIs in non-small-cell lung cancer comparing gefitinib or erlotinib vs placebo showed 
an improvement in tumor response rates with gefitinib ${ }^{36}$ and improved survival with erlotinib. ${ }^{37}$ Nevertheless, in studies comparing TKIs to standard chemotherapy, only one trial has shown an improved response in TKI-treated patients, while several other trials have failed to show superior efficacy of EGFR or HER2 inhibition. ${ }^{35}$ The phase II study from Harrington et al showed a superiority of lapatinib treatment in combination with chemoradiotherapy in p16-negative patients with locally advanced HNNSC, that nevertheless did not reach statistical significance. ${ }^{23}$ Moreover, due to the limited number of patients and the short follow-up period, in the same study it was not possible to evaluate the efficacy of lapatinib in p16-positive (surrogate marker of HPV infection) patients, and further studies are needed to address this point.

Our data suggest that lapatinib effectively inhibits the cell growth of two HPV-positive HNSCC cell lines and displays additive activity with ionizing radiation. Lapatinib was ineffective in HPV-negative HNSCC cells, suggesting that sensitizing effect of lapatinib is restricted to HPV-positive cells. Nevertheless, further studies are required to confirm HPV status as an indicator of the response to lapatinib and to identify the molecular mechanisms underlying the differential effects in HPV-positive vs uninfected cells.

\section{Acknowledgment}

This work was financially supported by Fondation Gustave Roussy, Institut National du Cancer (INCa), and GlaxoSmithKline.

\section{Disclosure}

The authors report no conflicts of interest in this work.

\section{References}

1. Bernier J, Bentzen SM, Vermorken JB. Molecular therapy in head and neck oncology. Nat Rev Clin Oncol. 2009;6(5):266-277.

2. Vermorken JB. Medical treatment in head and neck cancer. Ann Oncol. 2005;16(Suppl 2):ii258-ii264.

3. Chaturvedi AK, Engels EA, Anderson WF, Gillison ML. Incidence trends for human papillomavirus-related and -unrelated oral squamous cell carcinomas in the United States. J Clin Oncol. 2008;26(4):612-619.

4. Kong CS, Narasimhan B, Cao H, et al. The relationship between human papillomavirus status and other molecular prognostic markers in head and neck squamous cell carcinomas. Int J Radiat Oncol Biol Phys. 2009; 74(2):553-561.

5. Kimple RJ, Smith MA, Blitzer GC, et al. Enhanced radiation sensitivity in HPV-positive head and neck cancer. Cancer Res. 2013;73(15): 4791-4800.

6. Rieckmann T, Tribius S, Grob TJ, et al. HNSCC cell lines positive for HPV and 16 possess higher cellular radiosensitivity due to an impaired DSB repair capacity. Radiother Oncol. 2013;107(2):242-246.

7. Yarden Y. The EGFR family and its ligands in human cancer: signalling mechanisms and therapeutic opportunities. Eur J Cancer. 2001;37:3-8.
8. Kim S, Grandis JR, Rinaldo A, Takes RP, Ferlito A. Emerging perspectives in epidermal growth factor receptor targeting in head and neck cancer. Head Neck. 2008;30(5):667-674.

9. Cavalot A, Martone T, Roggero N, Brondino G, Pagano M, Cortesina G. Prognostic impact of HER-2/neu expression on squamous head and neck carcinomas. Head Neck. 2007;29(7):655-664.

10. Temam S, Kawaguchi H, El-Naggar AK, et al. Epidermal growth factor receptor copy number alterations correlate with poor clinical outcome in patients with head and neck squamous cancer. J Clin Oncol. 2007;25(16):2164-2170.

11. Laimer K, Spizzo G, Gastl G, et al. High EGFR expression predicts poor prognosis in patients with squamous cell carcinoma of the oral cavity and oropharynx: a TMA-based immunohistochemical analysis. Oral Oncol. 2007;43(2):193-198.

12. Chung $\mathrm{CH}$, Ely $\mathrm{K}, \mathrm{McGavran} \mathrm{L}$, et al. Increased epidermal growth factor receptor gene copy number is associated with poor prognosis in head and neck squamous cell carcinomas. J Clin Oncol. 2006;24(25): $4170-4176$.

13. Kumar B, Cordell KG, Lee JS, et al. EGFR, p16, HPV Titer, Bcl-xL and $\mathrm{p} 53$, sex, and smoking as indicators of response to therapy and survival in oropharyngeal cancer. J Clin Oncol. 2008;26(19):3128-3137.

14. Bonner JA, Harari PM, Giralt J, et al. Radiotherapy plus cetuximab for squamous-cell carcinoma of the head and neck. $N$ Engl J Med. 2006;354(6):567-578.

15. Cohen MH, Johnson JR, Chen Y-F, Sridhara R, Pazdur R. FDA drug approval summary: erlotinib (Tarceva) tablets. Oncologist. 2005;10(7): $461-466$.

16. Cohen MH, Williams GA, Sridhara R, et al. United States food and drug administration drug approval summary: Gefitinib (ZD1839; Iressa) tablets. Clin Cancer Res. 2004;10(4):1212-1218.

17. Kondo N, Tsukuda M, Ishiguro Y, et al. Antitumor effects of lapatinib (GW572016), a dual inhibitor of EGFR and HER-2, in combination with cisplatin or paclitaxel on head and neck squamous cell carcinoma. Oncol Rep. 2010;23(4):957-963.

18. Erjala K, Sundvall M, Junttila TT, et al. Signaling via ErbB2 and ErbB3 associates with resistance and epidermal growth factor receptor (EGFR) amplification with sensitivity to EGFR inhibitor gefitinib in head and neck squamous cell carcinoma cells. Clin Cancer Res. 2006;12(13): 4103-4111.

19. Rusnak DW, Affleck K, Cockerill SG, et al. The characterization of novel, dual ErbB-2/EGFR, tyrosine kinase inhibitors potential therapy for cancer. Cancer Res. 2001;61(19):7196-7203.

20. Geyer CE, Forster J, Lindquist D, et al. Lapatinib plus capecitabine for HER2-positive advanced breast cancer. $N$ Engl J Med. 2006;355(26): 2733-2743.

21. Harrington KJ, El-Hariry IA, Holford CS, et al. Phase I study of lapatinib in combination with chemoradiation in patients with locally advanced squamous cell carcinoma of the head and neck. J Clin Oncol. 2009;27(7):1100-1107.

22. Kimple RJ, Horton JK, Livasy CA, et al. Phase I study and biomarker analysis of lapatinib and concurrent radiation for locally advanced breast cancer. Oncologist. 2012;17(12):1496-1503.

23. Harrington K, Berrier A, Robinson M, et al. Randomised Phase II study of oral lapatinib combined with chemoradiotherapy in patients with advanced squamous cell carcinoma of the head and neck: rationale for future randomised trials in human papilloma virus-negative disease. Eur J Cancer. 2013;49(7):1609-1618.

24. Prétet JL, Jacquard AC, Carcopino X, et al; EDITH Study Group. Human papillomavirus (HPV) genotype distribution in invasive cervical cancers in France: EDITH study. Int $J$ Cancer. 2008;122(2):428-432.

25. Woodworth CD, Diefendorf LP, Jette DF, et al. Inhibition of the epidermal growth factor receptor by erlotinib prevents immortalization of human cervical cells by Human Papillomavirus type 16. Virology. 2011;421(1):19-27.

26. Chinnaiyan P, Huang S, Vallabhaneni G, et al. Mechanisms of enhanced radiation response following epidermal growth factor receptor signaling inhibition by erlotinib (Tarceva). Cancer Res. 2005;65(8):3328-3335. 
27. Zhou H, Kim Y-S, Peletier A, McCall W, Earp HS, Sartor CI. Effects of the EGFR/HER2 kinase inhibitor GW572016 on EGFR- and HER2overexpressing breast cancer cell line proliferation, radiosensitization, and resistance. Int J Radiat Oncol Biol Phys. 2004;58(2):344-352.

28. Sambade MJ, Camp JT, Kimple RJ, Sartor CI, Shields JM. Mechanism of lapatinib-mediated radiosensitization of breast cancer cells is primarily by inhibition of the Raf $>$ MEK $>$ ERK mitogen-activated protein kinase cascade and radiosensitization of lapatinib-resistant cells restored by direct inhibition of MEK. Radiother Oncol. 2009;93(3): 639-644.

29. Vermorken JB, Stöhlmacher-Williams J, Davidenko I, et al. Cisplatin and fluorouracil with or without panitumumab in patients with recurrent or metastatic squamous-cell carcinoma of the head and neck (SPECTRUM): an open-label phase 3 randomised trial. Lancet Oncol. 2013;14(8):697-710.

30. Giralt J, Fortin A, Mesia R, et al. A phase II, randomized trial (CONCERT-1) of chemoradiotherapy (CRT) with or without panitumumab (pmab) in patients (pts) with unresected, locally advanced squamous cell carcinoma of the head and neck (LASCCHN). J Clin Oncol. 2012;30(suppl; abstr 5502). Available from: http://meetinglibrary.asco. org/content/93724-114. Accessed April 25, 2014.

31. Plastaras JP, Kim SH, Liu YY, et al. Cell cycle-dependent and scheduledependent antitumor effects of sorafenib combined with radiation. Cancer Res. 2007;67(19):9443-9454.

32. Rusnak DW, Alligood KJ, Mullin RJ, et al. Assessment of epidermal growth factor receptor (EGFR, ErbB1) and HER2 (ErbB2) protein expression levels and response to lapatinib (Tykerb, GW572016) in an expanded panel of human normal and tumour cell lines. Cell Prolif. 2007;40(4):580-594.

33. Spangle JM, Munger K. The HPV16 E6 oncoprotein causes prolonged receptor protein tyrosine kinase signaling and enhances internalization of phosphorylated receptor species. PLoS Pathog. 2013;9(3):e1003237.

34. Straight SW, Herman B, McCance DJ. The E5 oncoprotein of human papillomavirus type 16 inhibits the acidification of endosomes in human keratinocytes. J Virol. 1995;69(5):3185-3192.

35. Krause M, Gurtner K, Deuse Y, Baumann M. Heterogeneity of tumour response to combined radiotherapy and EGFR inhibitors: differences between antibodies and TK inhibitors. Int J Radiat Biol. 2009;85(11):943-954.

36. Thatcher N, Chang A, Parikh P, et al. Gefitinib plus best supportive care in previously treated patients with refractory advanced nonsmall-cell lung cancer: results from a randomised, placebo-controlled, multicentre study (Iressa Survival Evaluation in Lung Cancer). Lancet. 2005;366(9496):1527-1537.

37. Shepherd FA, Rodrigues Pereira J, Ciuleanu T, et al; National Cancer Institute of Canada Clinical Trials Group. Erlotinib in previously treated non-small-cell lung cancer. $N$ Engl J Med. 2005;353(2):123-132.

38. Santin AD, Sill MW, McMeekin DS, et al. Phase II trial of cetuximab in the treatment of persistent or recurrent squamous or non-squamous cell carcinoma of the cervix: a Gynecologic Oncology Group study. Gynecol Oncol. 2011;122(3):495-500.

39. Farley J, Sill MW, Birrer M, et al. Phase II study of cisplatin plus cetuximab in advanced, recurrent, and previously treated cancers of the cervix and evaluation of epidermal growth factor receptor immunohistochemical expression: a Gynecologic Oncology Group study. Gynecol Oncol. 2011;121(2):303-308.

40. Kurtz JE, Hardy-Bessard AC, Deslandres M, et al. Cetuximab, topotecan and cisplatin for the treatment of advanced cervical cancer: a phase II GINECO trial. Gynecol Oncol. 2009;113(1):16-20.

41. Bourhis J, Rivera F, Mesia R, et al. Phase I/II study of cetuximab in combination with cisplatin or carboplatin and fluorouracil in patients with recurrent or metastatic squamous cell carcinoma of the head and neck. J Clin Oncol. 2006;24(18):2866-2872.
42. Merlano M, Russi E, Benasso M, et al. Cisplatin-based chemoradiation plus cetuximab in locally advanced head and neck cancer: a phase II clinical study. Ann Oncol. 2011;22(3):712-717.

43. Baselga J, Trigo JM, Bourhis J, et al. Phase II multicenter study of the antiepidermal growth factor receptor monoclonal antibody cetuximab in combination with platinum-based chemotherapy in patients with platinum-refractory metastatic and/or recurrent squamous cell carcinoma of the head and neck. J Clin Oncol. 2005;23(24):5568-5577.

44. Burtness B, Goldwasser MA, Flood W, Mattar B, Forastiere AA. Phase III randomized trial of cisplatin plus placebo compared with cisplatin plus cetuximab in metastatic/recurrent head and neck cancer: an Eastern Cooperative Oncology Group study. J Clin Oncol. 2005;23(34): 8646-8654.

45. Vermorken JB, Mesia R, Rivera F, et al. Platinum-based chemotherapy plus cetuximab in head and neck cancer. $N$ Engl J Med. 2008;359(11): $1116-1127$.

46. Goncalves A, Fabbro M, Lhommé C, et al. A phase II trial to evaluate gefitinib as second- or third-line treatment in patients with recurring locoregionally advanced or metastatic cervical cancer. Gynecol Oncol. 2008;108(1):42-46.

47. Chen C, Kane M, Song J, et al. Phase I trial of gefitinib in combination with radiation or chemoradiation for patients with locally advanced squamous cell head and neck cancer. J Clin Oncol. 2007;25(31):4880-4886.

48. Perez CA, Song H, Raez LE, et al. Phase II study of gefitinib adaptive dose escalation to skin toxicity in recurrent or metastatic squamous cell carcinoma of the head and neck. Oral Oncol. 2012;48(9):887-892.

49. Gregoire V, Hamoir M, Chen C, et al. Gefitinib plus cisplatin and radiotherapy in previously untreated head and neck squamous cell carcinoma: a phase II, randomized, double-blind, placebo-controlled study. Radiother Oncol. 2011;100(1):62-69.

50. Cohen EE, Haraf DJ, Kunnavakkam R, et al. Epidermal growth factor receptor inhibitor gefitinib added to chemoradiotherapy in locally advanced head and neck cancer. J Clin Oncol. 2010;28(20):3336-3343.

51. Nogueira-Rodrigues A, do Carmo CC, Viegas C, et al. Phase I trial of erlotinib combined with cisplatin and radiotherapy for patients with locally advanced cervical squamous cell cancer. Clin Cancer Res. 2008;14(19):6324-6329.

52. Schilder RJ, Sill MW, Lee Y-C, Mannel R. A phase II trial of erlotinib in recurrent squamous cell carcinoma of the cervix: a Gynecologic Oncology Group Study. Int J Gynecol Cancer. 2009;19(5):929-933.

53. Rusthoven KE, Feigenberg SJ, Raben D, et al. Initial results of a Phase I dose-escalation trial of concurrent and maintenance erlotinib and reirradiation for recurrent and new primary head-and-neck cancer. Int J Radiat Oncol Biol Phys. 2010;78(4):1020-1025.

54. Arias de la Vega F, Contreras J, de Las Heras M, et al; Members of GICOR (Grupo de Investigación Clínica en Oncología Radioterápica) Group. Erlotinib and chemoradiation in patients with surgically resected locally advanced squamous cell carcinoma of the head and neck: a GICOR phase I trial. Ann Oncol. 2012;23(4):1005-1009.

55. Soulieres D, Senzer NN, Vokes EE, Hidalgo M, Agarwala SS, Siu LL. Multicenter phase II study of erlotinib, an oral epidermal growth factor receptor tyrosine kinase inhibitor, in patients with recurrent or metastatic squamous cell cancer of the head and neck. J Clin Oncol. 2004;22(1): $77-85$.

56. Herchenhorn D, Dias FL, Viegas CM, et al. Phase I/II study of erlotinib combined with cisplatin and radiotherapy in patients with locally advanced squamous cell carcinoma of the head and neck. Int $J$ Radiat Oncol Biol Phys. 2010;78(3):696-702.

57. Del Campo JM, Hitt R, Sebastian P, et al. Effects of lapatinib monotherapy: results of a randomised phase II study in therapy-naive patients with locally advanced squamous cell carcinoma of the head and neck. Br J Cancer. 2011;105(5):618-627. 


\section{Supplementary materials}

Table SI Quantitative RT-PCR primers and thermal protocol

\begin{tabular}{ll}
\hline Primers & HPVI6-E6 F: GAG CGA CCC AGA AAG TTA CCA \\
sequences & HPVI6-E6 R: AAA TCC CGA AAA GCA AAG TCA \\
& HPVI6-E7 F: TCC AGC TGG ACA AGC AGA AC \\
& HPVI6-E7 R: CAC AAC CGA AGC GTA GAG TC \\
& $\beta-2$ microglobulin F: \\
& TGCTGTCTCCATGTTTGATGTATCT \\
& $\beta-2$ microglobulin R: \\
& TCTCTGCTCCCCACCTCTAAGT \\
Amplification & 10 minutes at $95^{\circ} \mathrm{C}$, then 40 cycles of I5 seconds at \\
program & $95^{\circ} \mathrm{C}$, and 60 seconds at $60^{\circ} \mathrm{C}$ \\
\hline
\end{tabular}

Table S2 Number of cells plated for clonogenic survival assays

\begin{tabular}{lllll}
\hline $\begin{array}{l}\text { Irradiation } \\
\text { dose (Gy) }\end{array}$ & $\begin{array}{l}\text { SCC-9 } \\
\text { (cells/well) }\end{array}$ & $\begin{array}{l}\text { SCC-I5 } \\
\text { (cells/well) }\end{array}$ & $\begin{array}{l}\text { SCC-47 } \\
\text { (cells/well) }\end{array}$ & $\begin{array}{l}\text { SCC-I54 } \\
\text { (cells/well) }\end{array}$ \\
\hline 0 & 250 & $\mathrm{I}, 000$ & 500 & $\mathrm{I}, 000$ \\
$\mathrm{I}$ & 375 & $\mathrm{I}, 500$ & 750 & $\mathrm{I}, 500$ \\
2 & 500 & 2,000 & $\mathrm{I}, 000$ & 2,000 \\
4 & $\mathrm{I}, 000$ & 3,000 & 2,000 & 3,000 \\
\hline
\end{tabular}

Table S3 List of antibodies

\begin{tabular}{llll}
\hline Antibody & Reference & $\begin{array}{l}\text { Catalog } \\
\text { number }\end{array}$ & $\begin{array}{l}\text { Amino acid } \\
\text { phosphorylation site }\end{array}$ \\
\hline Anti-AKT & $\begin{array}{l}\text { Cell Signaling } \\
\text { Technology } \\
\text { Cell Signaling }\end{array}$ & $\# 469$ I & \\
PAKT & $\begin{array}{l}\text { Technology } \\
\text { BD Biosciences }\end{array}$ & $\# 610017$ & Phospho-Akt (Ser473) \\
Anti-EGFR & $\begin{array}{l}\text { Cell Signaling } \\
\text { pEGFR }\end{array}$ & $\# 2234$ & $\begin{array}{l}\text { Phospho-EGFR } \\
\text { (Tyr 1068) }\end{array}$ \\
Anti-HER2 & $\begin{array}{l}\text { Technology } \\
\text { Cell Signaling }\end{array}$ & $\# 2242$ & \\
PHER2 & $\begin{array}{l}\text { Technology } \\
\text { Cell Signaling }\end{array}$ & $\# 2249$ & $\begin{array}{l}\text { Phospho-HER2 } \\
\text { (Tyr I22I/I222) }\end{array}$ \\
Anti- $\beta$-actin & $\begin{array}{l}\text { Technology } \\
\text { AbCam }\end{array}$ & Ab49900 & \\
\hline
\end{tabular}

OncoTargets and Therapy

\section{Publish your work in this journal}

OncoTargets and Therapy is an international, peer-reviewed, open access journal focusing on the pathological basis of all cancers, potential targets for therapy and treatment protocols employed to improve the management of cancer patients. The journal also focuses on the impact of management programs and new therapeutic agents and protocols on

patient perspectives such as quality of life, adherence and satisfaction. The manuscript management system is completely online and includes a very quick and fair peer-review system, which is all easy to use. Visit http://www.dovepress.com/testimonials.php to read real quotes from published authors. 